\title{
Active Engagement of the Intro IR Student: A Simulation Approach
}

\author{
William W. Newmann, Virginia Commonwealth University \\ Judyth L. Twigg, Virginia Commonwealth University
}

\begin{abstract}
Qtandard classroom lectures may not capture the imagination of students new to the subject of international relations, students for whom the Cold War seems as distant as the Peloponnesian War. In order to convey the full richness, complexity, drama, and importance of international affairs, we decided several years ago to add a role-playing simulation game to our freshman-level international relations course. In this article, we highlight the challenges and dilemmas we have encountered when engaging students in a simulation of the Indian and Pakistani dispute over Kashmir. We also address the strategies we have adopted to meet those challenges after repeated runs of this simulation over a four-year period.

Our goals in this endeavor were two-fold. From a pedagogical perspective, we hoped to increase the level and quality of contact between the students and faculty, provide students with greater opportunities for interacting and cooperating in large and small groups, facilitate active learning, and open alternate paths of learning and achievement for students who do not respond well to more conventional approach-
\end{abstract}

\footnotetext{
William Newmann is an assistant professor of political science and public administration at Virginia Commonwealth University. He researches U.S. presidential decision making for national security and U.S. and Asian foreign policy and security issues. His 1999 doctoral dissertation, completed at the University of Pittsburgh, won APSA's Leonard D. White Award.

\begin{abstract}
Judyth Twigg is an assistant professor of political science and public administration at Virginia Commonwealth University. Her principal research focuses on the politics of health care reform in the Russian Federation, and she is currently co-chair of a Carnegie Corporation study of social cohesion in Russia during the transition period.
\end{abstract}

es. ${ }^{1}$ In terms of course content, our intent was to allow the students to experience first-hand the concepts they had encountered in their textbooks, from theoretical ideas such as balance of power and realism, to the synergies among major concrete issues like international trade and arms control, to the nuance and detail-oriented nature of diplomacy. Although this content can certainly be taught without conducting simulations, bringing the textbook to life convinces students that these concepts are more than mere abstractions. By taking part in the Kashmir simulation, students begin to understand the frustrations of trying to achieve cooperation within anarchy, the difficulty and importance of precise communication, and the realities of power that are the foundation of diplomacy. We have also found that the simulation format provides students a better framework than do lecture notes for longterm retention of important international relations concepts.

\section{Mechanics of the Simulation}

\section{Why Kashmir?}

We chose a crisis in Kashmir as the substantive focus of the simulation because the complexity of the real-world Kashmir situation allows anyone proposing a resolution of the conflict to explore virtually every key international relations concept-from globalization to terrorism. The region became an object of contention between the then-newly independent states of India and Pakistan in 1947, when each nation claimed sovereignty over the area. Following an independence declaration and a war between India and Pakistan, a cease fire left the larger share of the region located in predominantly Hindu India, though its population is two-thirds Muslim. India and Pa- kistan have gone to war several times over the territory since then, and a United Nations observer force has been in place to monitor ongoing tensions since 1949. A study of the conflict over Kashmir quickly leads one to consider such issues as ethnic tensions and the treatment of religious minorities, strategic resource constraints, stunted economic development due to continued instability, the proper role of international organizations, nationalism in both India and Pakistan, the interplay between religion and politics, regional balance of power considerations, and, of course, nuclear weapons and ballistic missile proliferation and possible use.

\section{Role Assignment}

The simulation runs for three or four class sessions, with students acting as international policymakers seeking to resolve an acute crisis we have mock-created in the Kashmir region. Three or four weeks before the role playing begins we spend one class period (or about $50 \mathrm{~min}$ utes of a longer class session) giving the students a basic introduction to the simulation. This lecture serves two purposes: It provides students with a common core of basic background knowledge about the realworld situation in Kashmir and it introduces them to the concept and basic mechanics of the exercise. We also provide this information in greater detail on our course web sites, and we expect students to use those sites to think about and prepare for their simulation responsibilities (see http://saturn.vcu.edu/ $\sim$ wnewmann/syllabi/ sylsum00105.htm; www.wcb.vcu.edu/ wcb/schools/HAS/ssoa/jtwigg/3/).

During this preparatory class session, we distribute role assignments to each individual student. We have found that the simulation works best 
CAL FOR PAPERS

\section{Teaching Philosophy Symposium}

A statement on "teaching philosophy" is becoming an increasingly important piece of the professional portfolio, which contains materials such as your curriculum vitae, syllabi, and recent publications and conference papers. This porffolio represents your value as a faculty member of your current or potentially hiring departments

APSA is looking for submissions to a symposium of essays on developing a teaching philosophy. Send your essays to Sheilah Mann, APSA, $1527 \mathrm{New}$ Hampshire Avenue, NW, Washington, DC 20036-1206.

\section{Selected References on Teaching Philosophies}

Carnegie Foundation for the Advancement of Teaching www.carnegidfoundation.ore

\section{Preparing Future Program (PFF)} www. preparing-faculty.org

Chism, N.V. 1997-98 "Developing a Philosophy of Teaching Statement." Essays on Teaching Excellence: Toward the Best in the Academy. Atherns, GA: New Forums Press and the Professional and Organizational Development Network in Higher Education; 9(3).

Goodyear, G.E., and D. Allichin. 1998. "Statements of Teaching Philosophies." In To Improve the Academy, ed. M. Kaplan. Stillwater, OK: New Forums Press and the Professional and Organizational Development Network in Higher Education; 103-22.

Palmer, P. 1998. The Courage to Teach. San Francisco: Jossey-Bass. national Relations course meet for fifty minutes, three times per week. With this schedule, we have found that running the simulation for three or four consecutive class sessions is optimal, since such a schedule provides a continuity of events and affords the students sufficient time to achieve (or at least attempt) some degree of resolution of the simulated conflict. A similar schedule can work well for classes that meet twice a week for 75 minutes. For classes meeting once a week for three hours, we generally conduct the simulation in the latter half of each session over three consecutive weeks. While this may seem like a small amount of time, we have found that strict time limitations heighten the sense of crisis. In effect, time constraints simulate the pressure actual diplomats feel when they know that any delays in achieving resolution could result in casualties, refugees, and an expansion of the conflict.

\section{Playing the Game}

We do not distribute a set of formal rules for conducting the simulation. Instead, we tell the students in advance that we will initiate the exercise by announcing, at the beginning of the first session, a particular event that will create an acute crisis amidst the general conditions of tension. Generally, we hand out a onepage fictional news bulletin describing some low-level military action or terror incident that leads to clashes between Indian security forces and Pakistani-supported rebels. We then ask all students to meet with their groups in various parts of the room. All the students playing representatives of India, for example, are directed to go to the rear right corner of the room, Pakistan's representatives to the front left corner, and so forth. Once all the groups are assembled, we simply tell them "Go!"

Barely contained chaos generally reigns for the first 10 or 15 minutes, as students try to find their natural partners and potential allies and, at a more basic level, try to figure out what they are supposed to be doing. The first few times we ran the simulation we were apprehensive about the degree of initial confusion, but write briefly about what a defense sia's historic and current military capabilities and interests. ${ }^{2}$ Third acter will act when asked to deal student playing the Russian defense minister, for instance, must specuabout Russia's specific military interests in India, Pakistan, and Kashnir, able to contribute to a resolution the conflict, or what the Russian military might hope to gain from the situation. We give the students plenty of hints and a "head start" on these research papers by distributing detailed role descriptions (see Appendix $B$ for excerpts from some sample role descriptions). These can range from one to three singlespaced pages.

Most of the sections of our Inter- 
we have now come to realize that it is a healthy and necessary part of the process that forces students to adapt quickly to the demands of the overall exercise. During this initial period, the instructor and teaching assistants roam the room, providing basic logistical information about who is who and who is located where. The instructor also gives advice and assistance regarding negotiating tactics and strategies.

We provide "Action Forms" for students to record any agreements they reach, unilateral decisions or announcements they wish to make, military actions, or any other substantive "moves." The action forms force the students to focus their thoughts to the point of decision, and they also provide a written record of the simulation history. These forms contain several sections, which students are told to complete in as much detail as they find appropriate.

- A description of the immediate action or decision

- Strategic, long-term goals accomplished with this action

- Tactical, short-term goals accomplished with this action

- Other parties involved or potentially affected by this action

- Is this action openly communicated or secret?

The students quickly realize that they should be spending their time within their own delegations discussing and reaching unilateral decisions, conducting appropriate negotiations and reaching agreements with other players, and codifying each move on an action form. Completed forms are immediately submitted to the instructor, who must make a decision about how to treat each one individually. Sometimes the forms contain information about a participant's decision that should be announced promptly and publicly, in which case the instructor can interrupt the class (we have found a whistle to be one of the most important logistical elements of simulation play!) with a "breaking news bulletin." Other forms record medium- or longer-term decisions, which the instructor can hold and report to the class at the end of the session. Recently, we have found that posting these updates on the course web sites immediately after each simulation class helps students keep track of developments (see Appendix C for a sample update). These web site updates can also contain studentgenerated documents relevant to the simulation, such as proposed draft treaties to be considered at the next session.

In addition to the chaotic, freewheeling decision and negotiating sessions, we also require students to hold at least one formal meeting of an international organization, usually the United Nations Security Council. This provides some structure to the simulation and also gives students a chance to solve a specific short-term problem: Do we want to solve this crisis multilaterally through an intergovernmental organization? Prior to the first formal meeting, we ask that the students who feel their characters should address the official body place their names on a speakers' list, which encourages them to begin preparing their opening remarks and talking points. The students have repeatedly proven remarkably effective during these sessions, displaying the knowledge and insights they have gained through their role-specific research and also dramatic abilities worthy of Khrushchev's United Nations shoebanging. Once students discover the utility of both kinds of interactioninformal bargaining and formal meeting-they generally will self-engineer a back-and-forth pace between both formats, allotting 30-50 minutes for each segment. The Security Council meetings can be chaired by a delegate elected from within the Security Council, by the U.N. Secretary General, or by the instructor. (We have found it useful in any case for the instructor to intervene at least occasionally to interject analytic comments and provide necessary guidance.)

It would certainly be possible to conduct the entire simulation in a more formal manner, with something like a Security Council meeting as the format for the entire exer- cise. We have decided against imposing that larger degree of structure, however, because of the richness of the learning experience provided by the informal, "chaotic" back-and-forth conversation and negotiation among the players. The students learn in this way that reallife international politics is not always so neat and formal, that it is not always possible for every voice to be heard all the time, and that communication and order are valuable commodities that require effort to establish.

We have also found it useful to provide web-based bulletin boards for students to discuss the simulation in its preparatory, play, and post-play evaluation stages. During the several weeks in which students are preparing their research papers, they have used this forum as a vehicle for recommending and exchanging source materials in addition to ideas, strategies, and tactics. Once the simulation has actually begun, the bulletin boards become a location for group argument and discussion, and a tool for scheduling private meetings among allies. (We have become accustomed to receiving late-hour telephone calls from simulation delegations meeting in bars and restaurants.) One caveat is necessary here. If two or more sections of the course are running the same simulation simultaneously, it is important either to divide the bulletin boards accordingly, or to make sure that the students know to identify their sections when posting to the board. We have preferred the latter course of action, because students seem to benefit from exchanging ideas with their peers in other sections. We also encourage students to read the simulation updates posted for other class sections, so that they can learn from the similarities and differences in the way different "plays" of the same simulation are proceeding.

The simulation ends when the class sessions allotted for it have expired. We make it clear to the students from the beginning that we do not expect them to achieve any particular preordained resolution of the situation in three or four class periods, although we do want them 
to keep trying to resolve the conflict despite obstacles they may encounter. Of course, each run of the simulation plays out differently. Some classes require remarkably little intervention from the instructor. Others are dominated by players who come to unrealistically rapid agreements, in which case the instructor may need to interject new outside events to rekindle conflict. Still others will flow in the opposite direction, and the instructor will have to dampen an unrealistic propensity to resort to military force before other options have been exhausted. ${ }^{3}$

\section{Common Dynamics}

We have been continually delighted at the skill and detail with which the students put their research into practice. They play their roles with great respect for and knowledge of the international system and actors they are simulating. For example, we ran the Kashmir crisis simulation for several years without any of the parties resorting to the serious threat or use of nuclear weapons. The character of the simulations changed, however, after the Bharatiya Janata Party (BJP) came to power in real-world India by calling for an end to the separation between church and state, government based on Hindu principles, and development of nuclear weapons as a symbol of India's great power status. Role descriptions were rewritten to reflect the changing political dynamics in India, and, as in the real world, tensions increased. For the first time, nuclear weapons were either actually "used" or their use was seriously threatened during the simulation.

Second, we have found that international organizations, particularly the United Nations, tend to be marginalized during the simulation, while the United States and China, as great powers, tend to play enormously important brokering roles. Finally, in the course of each simulation, one or two countries or organizations which would not naturally be expected to be a major factor in the course of events are brought to the fore by particularly enthusiastic or outgoing students playing those roles. This last dynamic is not predictable, and while it may cause the simulation to stray somewhat from a careful reflection of the real world, we always encourage this unexpected activism from the student or students involved. (Straying from expected predictions of reality may not be as extreme as it seems as first glance-remember Norway and the Middle East peace settlement?)

\section{Troubleshooting Guide}

\section{Timing}

Because of the multidisciplinary nature of the Kashmir situation, we choose to conduct the simulation toward the end of the semester, after students have had the opportunity to complete their textbook learning about the issues that will be raised during the role-playing. Carrying out the simulation later in the term provides the additional benefit of familiarity, both between the instructor and the students and among the students themselves. In earlier semesters, we experimented with running the simulation around midterm, before we had covered issues of economic development and interdependence in the course. We found that students participating in these simulations neglected the economic dimensions of the crisis and, as a result, proved unable to find common ground between India and $\mathrm{Pa}$ kistan as motivation to resolve the conflict. The knowledge of economic development the students gain later in the semester changes the nature of the simulation.

\section{Class Size}

We have run this simulation in classes with as few as 20 and as many as 280 students. Obviously, it is more difficult to generate nearly 300 unique roles and role descriptions than it is to generate less than 30 , and classroom management in the larger classes is a daunting task. Producing the role descriptions is quite labor intensive initially, and each role description has to be updated each semester as political realities evolve. Fortunately, there are ways to make the generation of a large number of individual roles easier. The list of roles in Appendix A can be conveniently expanded with the addition of members to the UN Security Council to the real-world maximum of 15 , the inclusion of representatives of additional nongovernmental organizations, and the addition of members to major country delegations. Expanding country delegations can prove especially beneficial, since debates within their own delegations can teach students important lessons about the domestic sources of foreign policy. We have now compiled a bank of over 200 role descriptions, running to more than 400 pages.

Of course, the barely contained chaos of the informal sessions during simulation play becomes more difficult to manage as class size increases. For this, the teaching assistants play a critical role. When we first ran the simulation, we asked the TAs to spend their time roaming from delegation to delegation and to be maximally available to any student or group that might have a question or need guidance. Experience has shown, however, that it makes more sense to assign one teaching assistant permanently to each major country delegation. This arrangement permits the instructor to continue to play the part of roving crisis manager, seeking out those students or delegations who may need ideas for getting started, or moderating debates and conflicts within and between delegations.

\section{Role Assignments}

Deciding which roles to assign to which students is always difficult. At first, the task may seem obvious: assign the highest-profile, most visible roles to students who have proven their interests and abilities in the course by performing well on earlier exams and other assignments. This is, in fact, the strategy we have always followed, but it does present a dilemma. High-profile roles do carry the most responsibility (and therefore require that reliable and capable students play them if the simulation is to be a success), but they are also the easiest roles to research and perform, since those 
characters' relation to and interest in the Kashmir situation are clear. Less important roles, typically assigned to more average students, demand much more character development and interest assertiveness. This strategy for role assignment asks the marginal student to exhibit the most ingenuity and creativity, both in writing the research paper and in performing during the simulation itself. For this reason, we have been careful to provide plenty of guidance and pointed hints in the role descriptions we provide to students assigned seemingly minor simulation roles. Defense ministers, for example, are instructed to research the military balance of their nations' allies and enemies. Ambassadors are instructed to research the foreign policies of their assigned countries and to keep their respective foreign ministers apprised of what to expect from friend and foe. We also make sure that, to the greatest possible extent, all students receive equal attention from the instructor and TAs. It is crucial that all students, whatever roles they have been assigned, be made to understand that the significance of their parts in this exercise is limited only by their own imaginations and energy.

Fortunately, as we mentioned earlier, a small number (and usually more) of individual students to whom we have assigned minor roles always emerge as major actors during the course of the simulation itself. We always encourage these "surprise" major players, as their energy is inevitably a reflection of the simulation having provided a spark to these students' interest in the course material. Frequently, the result is that a completely unexpected country or nongovernmental organization will emerge as a major broker to a settlement between India and Pakistan over the Kashmir region.

On the other hand, some students who have performed brilliantly throughout the semester (and therefore have been assigned high-profile roles) may simply be quiet and reserved, or otherwise not possess personality traits that would make them likely to be outgoing and aggressive during simulation play. When major actors prove more inactive or docile than is appropriate for the simulation to proceed normally, we have found it necessary to encourage one or more of the "secondary" members of these delegations (e.g., cabinet members, undersecretaries general of the United Nations) to take on leadership functions without formally reassigning roles.

Sometimes, well-meaning students will become slightly overenthusiastic about the simulation, proposing acts of terrorism, assassination, sabotage, or other (usually military) activities either inappropriate in a general sense or out of line with the actual capabilities of their characters. For this reason, we require that each action form be explicitly approved by the instructor before that "action" can take effect. Usually, with guidance from the instructor or teaching assistants, a student's enthusiasm can be channeled into productive (and realistic) directions. Similarly, overly eager students will sometimes submit action forms containing agreements or treaties with other players without remembering that those other parties must also agree to the terms of such documents. This problem is easily solved by clearly and explicitly requiring that all parties to any agreement sign the relevant action form before that form is submitted to the instructor. Dissent within delegations can also be reflected through submission of action forms.

Assigning roles to international students can also be problematic. We have noticed that students who are citizens of the major countries in the simulation will frequently request the opportunity to play roles representing their homelands. Generally, we have refused these requests. One of the major purposes of this exercise is to have students conduct in-depth research on a region of the world with which they are not already familiar.

Finally, each semester we grapple with whether to post all the simulation role descriptions on the course web site. Even though posting the descriptions would provide significant logistical benefits, we have repeatedly decided against doing so. The simulation is much more inter-

\section{Appendix A Sample List of Roles for a Fiffy- to Sixty-Student Class}

India: Prime Minister, External Affairs Minister, Defense Minister, two leaders of opposition parties in the Lok Sahba (the Lower House of India's Parliament), leader of Jammu and Kashmir Liberation Front

Pakistan: President, Foreign Minister, Army Chief of Staff, two leaders of opposition parties in the National Assembly

China: General Secretary of Communist Party, Premier, Foreign Minister, Chicf of Staff of People's Liberation Army

United States: President, Secretary of State, Secretary of Defense

United Kingdom: Prime Minister, Foreign Secretary, Defense Secretary

France: President, Prime Minister, Foreign Minister

Russia: President, Prime Minister, Foreign Minister

Japan: Prime Minister, Foreign Minister, Finance Minister

Germany: Chancellor, Foreign Minister, Defense Minister

Indonesia: President, Foreign Minister, Defense Minister

Saudi Arabia: King, Foreign Minister, Defense Minister

Republic of South Africa: President, Foreign Minister, Defense Minister

Brazil: President, Foreign Minister, Defense Minister

South Asia Association for Regional Cooperation (SAARC) Contact Group representatives from Sri Lanka, Bangladesh, and Nepal

United Nations: Secretary General, Undersecretary General for Political Affairs, Undersecretary General for Peacekeeping Affairs, High Commissioner for Refugees, Chief Military Observer United Nations Military Observer Group in India and Pakistan (UNMOGIP)

Intergovernmental Organizations: Technical experts and inspectors from the International Atomic Energy Agency and the Comprehensive Nuclear Test Ban Treaty Organization

Nongovernmental Organizations: members of Human Rights Watch, Amnesty International, and Doctors Without Borders 


\section{Appendix B Two Sample Role Descriptions (abridged)}

\section{India Defense Minister (BJP)}

As one of the leaders of the largest single party in the Lok Sahba (the Lower House of India's Parliament) following the fall 1999 elections, you have just taken office as Defense Minister of India. You are a leader of a Hindu nationlist party, but in order to maintain power you have had to ally yourself with many regional parties that are not as dedicated to your Hindu agenda. There will therefore be restraints within your coalition to acting on your first instincts where Kashmir is concerned. You are trying to assure India's 120 million Muslims that they still have a place in a BJPgoverned India. They are skeptical.

You have talked in the past of the immediate development and deployment of nuclear weapons. After coming to power in 1998, your government began working on nuclear tests. On May 11 and 13, 1998, your government detonated five nuclear devices. You have shown the world that there is now a Hindu bomb to contend with. You fear a Chinese-Pakistani alliance, not just from a strategic perspective, but from apprehension about a Confucian-Islamic alliance bent on destroying Hindu culture. You want to use nuclear weapons to deter the Chinese threat you perceive. If your weapons heightened tensions between India and Pakistan, resulting, for example, in Pakistan's subsequent six nuclear tests in 1998 so be it. Your nuclear weapons and the deployment of those weapons on bombers, ballistic missiles, and strategic missile submarines will deter both China and Pakistan.

Of course, Kashmir is part of India at present, and you would like it to stay that way. You began to implement a more flexible policy in early 1999 with the signing of the Lahore Declaration, but this policy is now out of date to you. It came after you and the exPrime Minister of Pakistan met and agreed to work things out in Kashmir. The fighting in Kargil in the summer of 1999 and the military coup in Pakistan rendered it irrelevant. You, however may be willing to discuss the issue further for two reasons. First, you realize that economic growth is the key to India's future. India is the second most populous nation on the planet, the world's largest democracy, with an educated and technologically sophisticated elite and world-class diplomats, yet the majority of your people are still barely at the poverty level. The rest of the world seems to be making huge strides in economic development, and some say it is about time India did the same or else it will never be a major player on the world stage. Previous governments believed that economic growth depended in large part on gaining access to investment from foreign countries, and that in turn depended on investors' perceptions of the political and economic stability of the entire region. The previous government felt that stability may have depended on resolving all hostilities with Pakistan, your traditional rival. (Investors don't like to build factories in the middle of a war zone.) You, however, may change government policy. As a Hindu nationalist, you are wary of international investors and the continued opening of the economy to foreign economies, in the form of either foreign direct investment (foreign firms building factories in India) or foreign portfolio investment (foreign part-ownership in Indian firms). You worry about India's economy becoming too dependent on foreign nations. You point to what happened in East Asia when foreign investors suddenly perceived those economies as bad risks. They pulled their money out and sent those economies into a tailspin from which they will take years to recover. Simply put, your economic policies are still uncertain. You don't know how strong your coalition is, and your allies in the coalition believe in a more open economy.

Second, your possible ending of the separation of church and state makes everyone nervous about India. Perhaps progress in IndianPakistani relations might make them less apprehensive.

Your victory in the fall 1999 elections came on the heels of India's "victory" in the Kargil skirmish of that summer. Pakistani militants, clearly backed by the Pakistani military, attempted to capture territory in Kashmir near the town of Kargil. Indian troops rebuffed the attack, killed the militants, shot down some Pakistani military aircraft, and regained the territory. You criticized Pakistani terrorism and vowed never to give up Kashmir. You gained much credit for this incident. It was the Indian Armed Forces that pushed the Pakistani forces out of Kashmir. You immediately asked for increased defense spending and a full-fledged nuclear arsenal-ICBMs, SLBMs, and strategic bombers.
You have a rivalry with China that is made worse by its support for Pakistan. China's nuclear weapons make you nervous. You no longer have the Soviet Union as an ally against China, and the United States is, in your opinion, unreliable. A thaw in U.S.-China relations would be a problem for you. If the U.S. and China resolve some of their problems, you are the odd man out.

Your relationship with the United Nations has soured since you refused to sign the Comprehensive Test Ban Treaty (CTBT) However, the relationship has traditionally been very good. You do want a permanent seat on the United Nations Security Council, and, who knows, maybe that will be something worth bargaining for. Right now, you are probably not very enthused about the International Atomic Energy Agency (IAEA) and the Conference on Disarmament (CD), because of the CTBT. You are also not cooperating with nongovernmental human rights organizations, since they have accused you of repression in Kashmir

Your basic job is to advise the Prime Minister on all issues related to India's defense capabilities and the defense capabilities of its friends and enemies. You need to understand India's strengths compared to other powers in the region.

\section{China: Foreign Minister}

You are the foreign policy advisor to the General Secretary of the Communist Party and the Premier. Your job is to advise the senior leadership on China's overall national interests, both in a global sense (rivalries and friendships with the U.S., Russia, Japan) and a regional sense (the crisis in Kashmir and your relations with India and Pakistan). China's ambassadors to other nations work for you.

You see China as the equal of the United States, and you are both insulted and threatened by a U.S. policy that you perceive as one of containment of China. You are wary of a U.S.-Indian alliance, which could bottle you up on your western frontier. You have signed a treaty of friendship with Russia that talks of defending against U.S. expansion in East Asia. Coupled with the reversion of Hong Kong, this treaty has given China new confidence against what it perceives as an increasingly hostile U.S.-Japanese alliance in the region bent on containing Chinese power. You are increasingly suspicious of U.S. intervention in your internal affairs-Taiwan and human rights.

Your alliance with Pakistan is a way to weaken India, a nation you fought in the early 1960s. You will probably represent Pakistan's interests in international forums. You have been providing Pakistan with nuclear weapons and ballistic missile technology. Although you lean toward Pakistan, a major crisis such as this, so close to your borders, gives you the opportunity to play peacemaker on the world stage, a role the United States seems to want to reserve for itself.

You are a bit nervous about India's new BJP government. India detonated five nuclear weapons in May of 1998, which makes you very concerned; its ballistic missile capability may soon enable it to use nuclear weapons against you. You have been able to targe India with nuclear weapons for quite some time, and you liked the advantage you had. So you will continue to aid Pakistan's attempts to maintain the nuclear balance in South Asia. You may see the possibility that tensions short of war can benefit you.

You are a permanent member of the UN Security Council. You have yet to throw your weight around in this forum, but you may feel free to use your veto power if you see Pakistan getting the short end of the deal or if the United States tries to dominate Security Council proceedings. You most likely will ignore the religious aspects of the Kashmir conflict.

Deng Xiaoping, your paramount leader, died in February 1997. There is no formal succession process in your country, so the Premier and the General Secretary are your allies but also your rivals. You are uncertain whether bold moves will be the key to your success, exploiting nationalism to gain support of senior officials in the Party and the military, or whether provocative action will make you appear reckless and unsuitable for a higher leadership position. Since your primary focus is sustained and stable economic growth, you must be careful how much of that you risk in pursuit of foreign policy goals. Nationalism is a useful tool for maintaining domestic power, but if it gets out of control it could force you to take actions that might jeopardize that economic growth by threatening those nations who provide investment (especially Taiwan, Japan, and the U.S.) 
esting if students are unable to read each other's role descriptions. This is as true for members of individual country delegations as it is for members of different delegations. If we have provided strategic hints to particular countries on, for instance, how they might bargain with others, obviously those hints should be kept secret. But the role domestic politics plays in determining foreign policy outcomes also comes into play. For example, while the foreign ministers of the Indian and Pakistani delegations might be steered in their role descriptions toward an emphasis on arms control, the defense ministers might be asked to think about the possibility that the possession of nuclear weapons by both countries enhances deterrence and therefore lessens the probability of conventional war. When the students within each delegation are not aware of these potential within-country differences before the simulation begins, they are often surprised at the amount of time they spend deliberating and debating within their own delegations. And, of course, we as instructors are delighted to point out to them the ways in which their experience is therefore reflecting the real-world construction of foreign policy.

\section{Applications}

Although this article details our experience in simulating a largely security-oriented crisis for an international relations course, it is easy to imagine the format being used in a much wider range of applications. In order to simulate a crisis situation other than Kashmir, for example, it would simply be necessary to write different role descriptions for the students reflecting major players in an alternate real-world hot-spot. In this way, the simulation could focus on Northern Ireland, the Middle East, Chechnya, or virtually anywhere else in the world, with the instructor choosing any crisis that illustrates the desired international relations concepts.

Nor would the simulation have to deal exclusively with national security issues. An instructor wanting to stress concepts of globalization, for instance, could focus students on economic interdependence and create more roles for trade and finance ministers and representatives of multinational corporations and other nongovernmental interests. The precipitating crisis for such a simulation might be a currency crash, stock market decline, or trade negotiation failure. Indeed, the simulation could be applied to political science courses other than the basic international relations course, simply by changing the substance of the roles assigned to students and the nature of the crisis being solved.

\section{Debriefing and Evaluation}

Holding at least one formal debriefing session is useful after the last class session of simulation play. Although students can follow the progress of the simulation on the course web site, this final debriefing allows a collective summation of the exercise and, more importantly, facilitates explicit discussion of the ways in which the simulation illustrated important international relations concepts. Although linking simulated events to textbook material occurs informally in the course of discussions during the simulation itself, with the instructor periodically halting play in order to make conceptual points, too much interference by the instructor in this way interrupts the flow of events. A final wrap-up session is a good time to tie loose ends together, letting the instructor ensure that the students have made all the desired connections between the simulated events and the international relations concepts those events were designed to illuminate.

We have primarily based students' simulation grades on the role-focused research papers they submit before the simulation begins. To assess student performance during the simulation itself (and to encourage attendance during the simulation sessions), we have also required students to submit short post-simulation essays, or we have put questions about the actual functioning of the simulation on the final examination.

\section{Appendix C Sample Summary of Simulation Events for a Single Class Session, Posted on Course Web Site}

UN Security Council meeting minutes, Wednesday, November 25, 10:00 - 10:50 class

The first speaker was a representative from the United Nations Secretary General's office. He proposed UNSC Resolution 001, a proposal to increase the number of UNMOGIP troops to 1,000 . That resolution passed by a vote of $10-0$. Another proposal, to place a UN observer force throughout the land mass of Kashmir, was scuttled because of India's lack of invitation. Britain has offered its own troops and artillery units to any military observer force that is created.

The next speaker was the Indian Prime Minster. He demanded an immediate lifting of economic sanctions. He also insisted that outside intervention in the Kashmir crisis was causing more problems than it solves. He offered to release to Pakistan the Pakistani citizen being held under arrest for the school bus bombing. Finally, he stated that India will sign the CTBT under two conditions: the lifting of economic sanctions and Pakistan's signing of that treaty.

Questioning and heated debate followed, with speeches from SAARC, Pakistan, Britain, the Conference on Disarmament, Amnesty International, and Russia. The discussions focused on human rights violations in the Indian part of Kashmir, the legitimacy of economic sanctions against India and Pakistan, and the motivation for India's and $\mathrm{Pa}$ kistan's nuclear weapons tests.

The Security Council voted on UNSC Resolution 002 , on the unconditional lifting of economic sanctions from India and Pakistan The vote failed 8-2, with only South Africa and Japan voting "Yes."

The final speaker at the meeting was Pakistan, who made it clear that Pakistan's nuclear weapons tests took place only in response to India's. Pakistan also reminded the UNSC that the promised plebiscite in Kashmir has never taken place.

In the final event of the meeting, Pakistan offered to sign the CTBT.

In related activity outside the formal UNSC meeting:

1. The IAEA has spoken with China and Saudi Arabia about the NPT and the CTBT, hoping that this will influence $\mathrm{Pa}$ kistan to cooperate.

2. SAARC has announced that it would like to approach the UN about direct peace talks between India and Pakistan. SAARC would also like to offer its services as a mediator group to this conflict, reasoning that this is a South Asian matter that can best be handled by South Asians. SAARC would also like the international community to be reminded that due to its countries' economic interdependence with India and Pakistan, the economic sanctions currently in effect harm the smaller, innocent SAARC countries as well. 
It would also be possible to assign subjective grades to each student reflecting the quality of his or her actual simulation play, but we have avoided doing so because we recognize the impossibility of directly observing each individual student's performance.

Student reaction to the Kashmir simulation has been overwhelmingly positive. We conduct both informal verbal and formal written assessments at the end of the course to assess student response to this learning exercise. Students' feedback clearly reflects success in achieving the goals we outlined at the beginning of this article. In particular, students seem to value the opportunity for active learning; they consistently report surprise at the degree to which their understanding of text- book concepts is enhanced by "living" those concepts in practice. Students frequently say that until the simulation, they had no idea that diplomacy would be so difficult; they come to respect the idea that "the devil is in the details" of any attempt to reach international or domestic consensus. The students and instructors also value the opportunity for faculty-student interaction, particularly in the larger classes. And, as evidenced by those instances in which some students unexpectedly emerge as major participants during simulation play, this exercise clearly harnesses and respects different learning styles, allowing students who may not excel at the standard multiple-choice or essay exam to find an opportunity to flourish.

In sum, we highly recommend us- ing this or a similar simulated roleplaying exercise as a teaching tool in a basic international relations course of any size. As we have developed the simulation over the course of the last several years, we have witnessed consistent student enthusiasm and substantial benefit in terms of student understanding and learning. Perhaps most importantly, virtually all the participants come away from the simulation having had fun.

Given the number of times we hear comments like "I never used to read anything but the sports (or comics) section of the newspaper, but now I check the world news section every day," we feel confident that we are helping students develop a positive attitude toward the course and, we hope, toward continued attention to international affairs.

\section{Notes}

1. Throughout the planning and implementation of the simulation, we have been guided by the literature on active learning and general education. See, for example, Chickering and Gamson (1987), and the subsequent discussion and elaboration in Barr and Tagg (1995), Stalheim-Smith (1998), Boggs (1999), and Ehrmann (1999).

2 . The standard caveats apply here in terms of students using web sources for a research paper. We have found it important to warn students that not all web sites with information about the Kashmir situation are politically impartial, and that they should be very careful to investigate and make informed judgments about the author of any site they choose as a source.

3. One class was allowed to take its more militaristic strategies to their conclusion. A Russian-Chinese alliance invaded Kashmir and only pulled back when NATO troops reached the outskirts of Moscow. This was a highly unusual case. In repeated runs of this simulation, only two have led to the use of military force by any groups save the immediate combatants in Kashmir.

\section{References}

Barr, Robert B., and John Tagg. 1995. "From Teaching to Learning-A New Paradigm for Undergraduate Education." Change 27(November/December): 12.

Boggs, George R. 1999. "What the Learning Paradigm Means for Faculty." AAHE Bulletin, January.
Chickering, Art, and Zelda Gamson. 1987. "Seven Principles of Good Practice in Higher Education." AAHE Bulletin, March.

Ehrmann, Stephen C. 1999. "Asking the Hard Questions About Technology Use and Education." Change 31(March/April): 24-30.
Stalheim-Smith, Ann. 1998. "Focusing on Active, Meaningful Learning," IDEA Paper No. 34. Manhattan: Kansas State University. 